\title{
PENINGKATAN PENGETAHUAN REMAJA TENTANG GIZI DAN KESEHATAN REPRODUKSI
}

\author{
Andi Muh Asrul Irawan ${ }^{1}$, Zakia Umami ${ }^{1}$, Lusi Anindia Rahmawati ${ }^{1}$ \\ ${ }^{I}$ Gizi, Fakultas Sains dan Teknologi, Universitas Al Azhar Indonesia, \\ Komplek Masjid Agung Al Azhar, Jl. Sisingamangaraja, Kebayoran Baru Jakarta Selatan 12110 \\ Email Penulis Korespondensi: asrul.irawan@uai.ac.id
}

\begin{abstract}
Abstrak
Masa remaja merupakan periode terjadinya pertumbuhan dan perkembangan secara dinamis dan pesat, baik fisik, psikologis, intelektual, sosial, tingkah laku, seksual yang dikaitkan dengan pubertas. Masa remaja merupakan peralihan dari masa remaja ke dewasa. Pertambahan berat dan tinggi badan mengikuti perkembangan kematangan seksual. Pentingnya pengetahuan tentang status gizi serta masalah masalah kesehatan reproduksi pada remaja untuk dapat mencegah masalah yang mungkin timbul karena kurangnya pengetahuan remaja mengenai kesehatan mereka.Tujuan pengabdian masyarakat adalah untuk meningkatkan pengetahuan remaja terkait. Metode pelaksanaan pengabdian masyarakat ini berupa pelatihan cara mengukur status gizi remaja, pemberian materi mengenai kesehatan reproduksi remaja, pengetahuan remaja diukur menggunakan desain one group pre-posttest. Siswa diberikan pertanyaan yang mengukur pengetahuan tentang gizi dan kesehatan reproduksi.Skor Rata-rata pengetahuan siswa sebelum diintervensi dengan Pendidikan gizi sebesar $5,06 \pm 1,83$, setelah dilakukan intervensi Pendidikan gizi, skor rata-rata siswa meningkat sebesar $8,22 \pm 1,22$, hal ini menunjukan terjadi peningkatan pengetahun siswa tentang gizi dan kesehatan reproduksi.
\end{abstract}

Kata kunci: Remaja, Pendidikan Gizi Pengetahuan, Reproduksi

\begin{abstract}
Adolescence is a period of dynamic and rapid growth, including physical, psychological, intellectual, social, behavioral, sexual relations with puberty. Adolescence is a transition from adolescence to adulthood. Weight gain and height follow the development of sexual maturity. The importance of knowledge about nutritional status and reproductive health issues in adolescents to be able to prevent problems that may arise due to the lack of knowledge of adolescents about their health. Community development was to increase the knowledge of adolescents. This method of implementing community development was how to measure the nutritional status of adolescents, providing material on adolescent reproductive health, adolescent knowledge was measured using a one group pre-post-test design. The mean of students' knowledge score before intervention with Nutrition Education was 5,06 $\pm 1,83$, after nutrition education interventions, the mean of student knowledge score increased by 8,22 $\pm 1,22$, it showed that the knowledge of students about nutrition and reproductive health was increased.
\end{abstract}

Keywords: Adolescence, Nutrition Education, Knowledge, Reproduction 


\section{PENDAHULUAN}

Masa remaja merupakan periode terjadinya pertumbuhan dan perkembangan yang terjadi secara dinamis dan pesat baik fisik, psikologis, intelektual, sosial, tingkah laku seksual yang dikaitkan dengan mulai terjadinya pubertas. Masa remaja merupakan bagian dari proses tumbuh kembang, yaitu masa peralihan dari anak menuju dewasa. Pada tahap ini, anak mengalami percepatan pertumbuhan, perubahan-perubahan baik fisik maupun psikologis (Marcell, Wibbelsman, \& Seigel, 2011)

Pada masa pertumbuhannya remaja sering mengalami masalah kesehatan yang disebabkan oleh kurang nya pengetahuan dan pendidikan tentang kesehatan. WHO juga menyebutkan bahwa selama ini telah terjadi pengabaian terhadap fase kehidupan remaja baik di bidang riset, pendidikan maupun pelayanan kesehatan.

Populasi remaja saat ini diperkirakan 40 juta jiwa sehingga intervensi terhadap remaja merupakan salah satu strategis yang baik bagi pembangunan sumber daya manusia. Lingkungan mengalami perubahan besar selama masa remaja dan sering memainkan peran yang beresiko pada status kesehatan remaja.

Remaja mulai mengalami perubahan fisik, baik massa otot, massa tulang maupun massa lemaknya. Namun terdapat perbedaan antara laki-laki dan perempuan. Pertumbuhan perempuan lebih cepat dibandingkan dengan laki-laki karena terjadi peningkatan massa lemak pada perempuan sedangkan pada lakilaki lebih banyak mengalami pertambahan massa otot.

Salah satu cara untuk mengetahui pertumbuhan remaja adalah dengan melakukan pengukuran status gizi, baik secara langsung maupun tidak langsung. Salah satu cara sederhana adalah dengan melakukan pengukuran berat badan, tinggi badan serta pengukuran komposisi tubuh pada remaja.

Pertambahan berat dan tinggi badan juga mengikuti perkembangan kematangan seksual remaja. Anak remaja putri mengalami pacu tumbuh (penambahan TB dan BB) dengan cepat sebelum timbulnya tanda seks sekunder, pada usia rata-rata 8-9 tahun, sedangkan menarche terjadi rata-rata pada usia 12 tahun. Pada anak remaja putra, pacu tumbuh mulai terjadi sedikit lebih lambat pada usia sekitar 1011 tahun, sedangkan perubahan suara terjadi pada usia 13 tahun. Penyebab terjadi makin awalnya tanda-tanda pertumbuhan ini diperkirakan karena faktor gizi yang semakin baik, rangsangan dari lingkungan, iklim, dan faktor sosio-ekonom (Soejoeti, 2001)

Pentingnya pengetahuan tentang status gizi dan masalah kesehatan reproduksi pada remaja untuk dapat mencegah masalah-masalah yang timbul karena kurangnya pengetahuan serta kesadaran remaja mengenai kesehatan reproduksi mereka. Penelitian yang dilakukan pada remaja di SMA Kecamatan Buleleng Tahun 2010 menunjukan bahwa tingkat pengetahuan remaja mengenai kesehatan reproduksi masih kurang serta perilaku terhadap kesehatan reproduksi sebagian besar mengarah ke negatif (Wijaya, Agustini, \& MS, 2014)

Pendidikan dapat meningkatkan pengetahuan seseorang, dengan adanya peningkatan pengetahuan maka diharapkan akan terjadi perubahan perilaku yang lebih baik terhadap gizi dan kesehatan (Machfoedz \& Suryani, 2009).Program pendidikan kesehatan dan gizi pada remaja merupakan salah satu cara untuk menerapkan intervensi kesehatan global secara sederhana dan efektif untuk memperoleh pendidikan yang lebih luas(Jukes \& Bundy, 2008)

Menurut Healthy People 2010 (Departement of Health and Human Service, 2000) Pendidikan gizi akan meningkatkan pengetahuan gizi dan akan membantu sikap anak yang dapat mempengaruhi kebiasaan anak dalam memilih makanan dan snack yang menyehatkan. Pengaruh pendidikan gizi terhadap kesehatan mungkin akan lebih efektif jika targetnya adalah langsung pada remaja.[6]

Mengacu dari faktor tersebut, maka masalah yang disajikan adalah " seberapa besar pengaruh pendidikan gizi terhadap peningkatan pengetahuan remaja terkait gizi dan kesehatan reproduksi”. Penelitian ini bertujuan untuk mengetahui pengaruh pendidikan gizi terhadap peningkatan pengetahuan remaja terkait gizi dan kesehatan reproduksi 


\section{METODE PELAKSANAAN}

Kegiatan pengabdian masyarakat ini merupakan kerjasama Universitas Al Azhar Indonesia dengan Suku Dinas Pendidikan I \& II Wilayah Jakarta Selatan dan Suku Dinas Pendidikan I \& II Wilayah Jakarta Pusat dengan mengundang SMA se-Jakarta Pusat dan Selatan.Kegiatan pengabdian masyarakat berupa edukasi gizi dan kesehatan reproduksi serta simulasi pengukuran status gizi. Permainan untuk meningkatkan pengetahuan remaja mengenai gizi dan kesehatan reproduksi.

Peserta yang terlibat sebanyak 20 siswa yang berasal dari 5 sekolah SMA/SMK sederajat di Jakarta. Jumlah siswa dengan jenis kelamin perempuan sebanyak 12 orang, sedangkan Laki-laki sebanyak 8 orang. sebelum peserta diberikan pendidikan gizi berupa penyuluhan, peserta diberikan tugas (pre-post) yang berisi pertanyaan mengenai gizi, PHBS, pola makan sehat, penyakit tidak menular dan kesehatan reproduksi.

Setelah menyelesaikan pre-test, peserta kemudian diberikan penyuluhan berupa informasi mengenai gizi dan kesehatan reproduksi. Selain itu peserta diberikan permainan yang dapat meningkatkan pengetahuan, contohnya permainan tebak kata dan tebak gaya yang kalimatnya berhubungan dengan gizi.

Sebelum diberikan tugas akhir (post-test), peserta diberikan pelatihan berupa simulasi pengukuran status gizi dan interpretasi nya. Untuk mengukur keberhasilan Pendidikan gizi yang diberikan, peserta diberikan tugas akhir post-test kemudian hasil pre-post tes akan diuji secara statistik menggunakan uji paired sample t test.

\section{Pengenalan dan Simulasi pengukuran Status Gizi}

Penyuluhan yang dilakukan dalam kegiatan pengabdian masyarakat ini pemberian materi mengenai pentingnya memantau status gizi dan cara pengukuran status gizi yang benar. Hal ini dilakukan untuk meningkatkan pengetahuan remaja mengenai cara pengukuran dan mengetahui interpretasi hasil pengukuran status gizi untuk menjaga berat badan dan kesehatan mereka.
Alat yang digunakan untuk mengukur berat badan peserta berupa microtoise, sedangkan alat yang digunakan untuk mengukur berat badan menggunakan timbangan digital. Peserta diberikan simulasi pengukuran yang benar dan kesempatan untuk mengukur peserta lain.

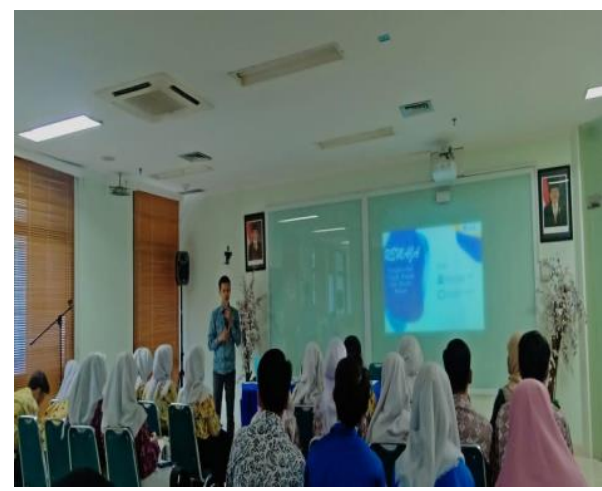

Gambar 1. Pengenalan Cara Pengukuran Status Gizi

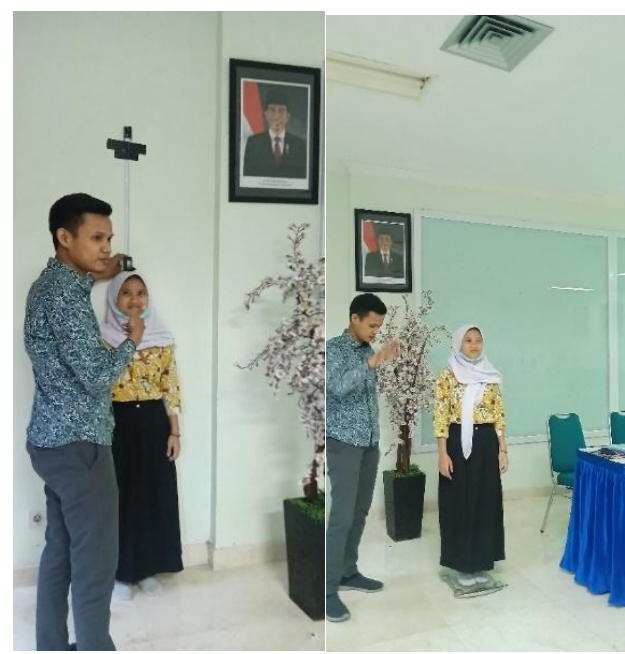

Gambar 2. Simulasi Pengenalan Cara Pengukuran Status Gizi

\section{Pendidikan gizi mengenai interpretasi hasil pengukuran status gizi}

Hasil pengukuran berat badan dan tinggi badan dapat menjadi gambaran status gizi remaja. Indeks Massa Tubuh (IMT) hasil dari pengukuran berat badan dan tinggi badan remaja memberikan gambaran status gizi normal, gemuk atau kurus pada remaja. Peserta diajarkan cara menghitung status gizi masingmasing agar peserta benar-benar paham pentingnya pengukuran status gizi secara berkala.

Remaja dengan status gizi kurang dan obesitas dapat memberikan dampak negatif bagi kesehatan, kecenderungan terjadi infeksi, 
anemia, penyakit jantung, serta masalah kesehatan lain yang menurunkan produktivitas pada remaja

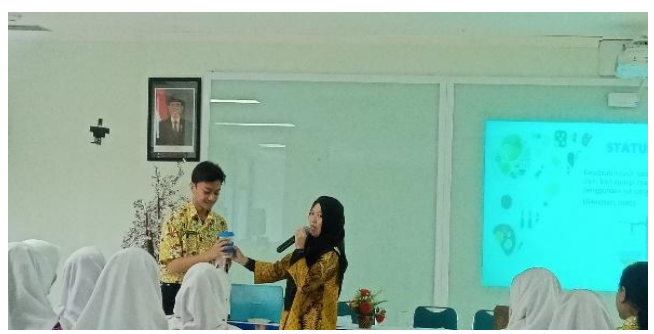

Gambar 3.Pendidikan Gizi Mengenai Interpretasi hasil Pengukuran Status Gizi

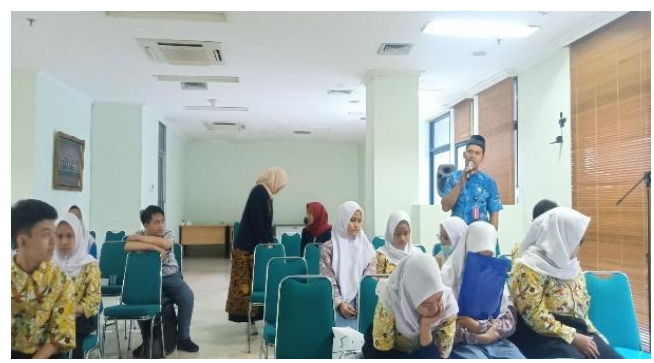

Gambar 4. Diskusi dan Tanya Jawab

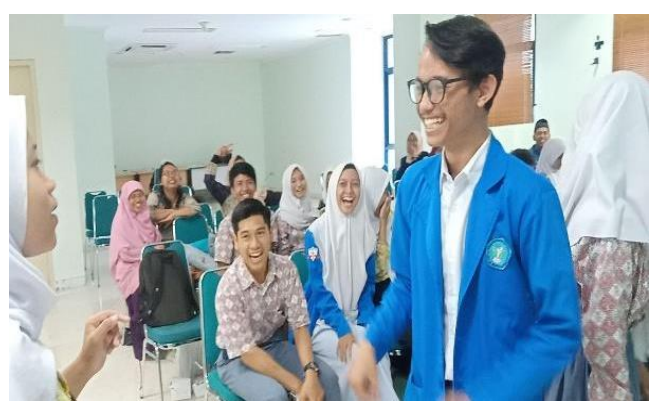

Gambar 5. Permainan Tebak Gaya dengan Kalimat Terkait Kesehatan Reproduksi

\section{Pendidikan gizi mengenai kesehatan reproduksi pada remaja}

Pentingnya pengetahuan tentang status gizi dan masalah kesehatan reproduksi pada remaja untuk dapat mencegah masalahmasalah yang timbul karena kurangnya pengetahuan serta kesadaran remaja mengenai kesehatan reproduksi mereka. Materi yang diberikan seputar kesehatan reproduksi, pentingnya pemantauan berat badan, serta masalah kesehatan yang mungkin timbul pada remaja

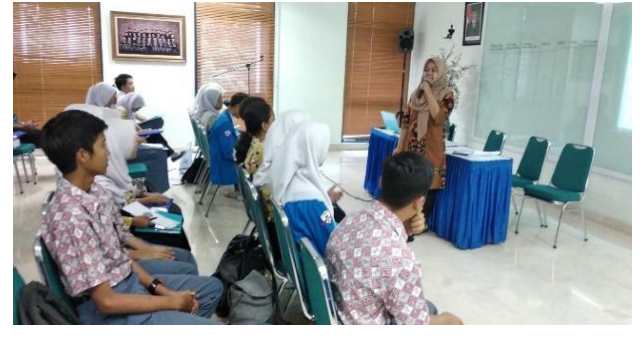

Gambar 6. Pendidikan Mengenai Kesehatan Reproduksi

\section{HASIL DAN PEMBAHASAN}

\section{Simulasi pengukuran dan Pendidikan mengenai Status Gizi}

Proses simulasi pengukuran status gizi serta interpretasi hasil pengukuran menggunakan cakram status gizi remaja. Peserta sangat antusias dengan materi Pendidikan yang diberikan, hal ini ditandai dengan pertanyaan yang berkaitan dengan kondisi status gizi mereka.

Total peserta yang hadir pada kegiatan ini adalah 20 orang yang berasal dari beberapa sekolah di Jakarta. Kegiatan ini merupakan kegiatan yang diinisiasi oleh Lembaga Penelitian dan Pengembangan Masyarakat (LPPM) Universitas Al Azhar Indonesia bekerja samadengan Suku Dinas Pendidikan Jakarta Selatan dan Jakarta Pusat.

Sebagian besar peserta yang hadir berasal dari SMKN 28 Jakarta, SMK Farmasi, SMAN 24 Jakarta dan SMK Triguna. Masing-masing sekolah didampingi oleh guru.Diharapkan keterlibatan guru dapat menjadi pemicu kesadaran siswa di sekolah meningkat

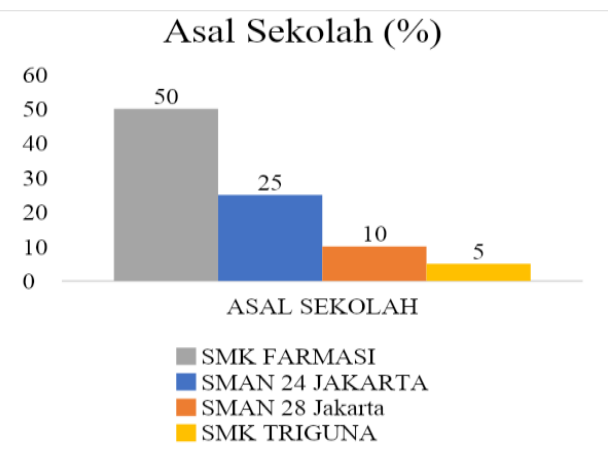

Gambar 7. Jumlah Peserta Berdasarkan Asal Sekolah 


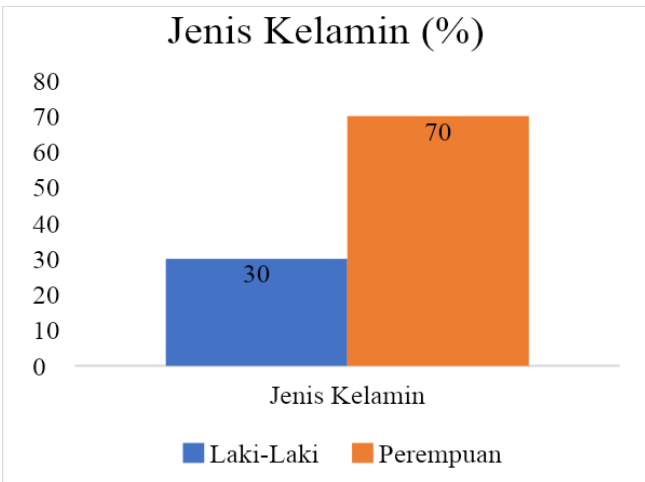

Gambar 8. Jumlah Peserta Berdasarkan Jenis Kelamin

Sebagian besar peserta berjenis kelamin perempuan $(70 \%)$ perempuan menjadi salah satu target Pendidikan gizi yang baik guna menyiapkan generasi masa depan. Intervensi pendidikan pada perempuan dapat menjadi aset untuk perempuan mempersiapkan diri menjadi ibu yang dapat menerapkan pengetahuan terkait gizi dan kesehatan reproduksi

\section{Pendidikan gizi mengenai gizi dan kesehatan reproduksi}

Kesehatan reproduksi pada remaja penting untuk diketahui dan disebarluaskan pada peserta, hal ini berkaitan dengan persiapan diri mereka menjadi orang tua, usia remaja merupakan usia produktif baik secara fisik maupun seksual.

Materi yang diberikan berupa pedoman hidup sehat yang mencakup pola hidup bersih, pentingnya aktivitas fisik remaja yang sekarang cenderung kurang aktif karena terlalu banyak bermain gadget, minum air putih secara teratur dan cukup, serta beberapa materi lain yang berhubungan dengan perilaku remaja selain itu diberikan juga materi terkait penyakit tidak menular pada remaja serta dampak kesehatan reproduksi pada remaja.

Pendidikan dapat meningkatkan pengetahuan seseorang, dengan adanya peningkatan pengetahuan maka diharapkan akan terjadi perubahan perilaku yang lebih baik terhadap gizi dan kesehatan. Diakhir kegiatan peserta diberikan pertanyaan yang dapat menggambarkan hasil atau evaluasi pendidikan gizi yang diberikan.
Hasil pre-post-test dianalisis menggunakan uji paired t test untuk melihat perbedaan ratarata sebelum intervensi Pendidikan dan setelah intervensi Pendidikan. Hasil uji analisis dapat dilihat pada Tabel 1:

Tabel 1.Uji Hasil pre-post Test Pengetahuan Siswa

\begin{tabular}{lll}
\hline Pengetahuan Gizi & Rerata \pm SD & $\mathrm{p}$ \\
\hline Sebelum & $5,06 \pm 1,83$ & \multirow{2}{*}{$0,000^{*}$} \\
Setelah & $8,22 \pm 1,2$ & \\
\hline "Paired sample t test & &
\end{tabular}

Berdasarkan Tabel 1 uji hasil pengetahuan menunjukan bahwa terjadi peningkatan pengetahuan siswa setelah intervensi Pendidikan gizi.Hasil ini menunjukan bahwa intervensi Pendidikan dapat meningkatkan pengetahuan siswa, diharapkan melalui Pendidikan gizi ini dapat meningkatkan kesadaran pada remaja terkait kesehatan reproduksi mereka.

Pendidikan dan pengetahuan merupakan faktor tidak langsung yang mempengaruhi perilaku seseorang. Pengetahuan yang didapat seseorang tidak terlepas dari pendidikan. Menurut Healthy People 2010 Pendidikan gizi akan meningkatkan pengetahuan gizi dan akan membantu sikap anak yang dapat mempengaruhi kebiasaan anak dalam memilih makanan dan snack yang menyehatkan. Pengaruh pendidikan gizi terhadap kesehatan mungkin akan lebih efektif jika targetnya adalah langsung pada remaja [6]

\section{SIMPULAN DAN SARAN}

Pengetahuan mengenai gizi dan kesehatan reproduksi pada remaja termasuk rendah, setelah diberikan intervensi Pendidikan terjadi perubahan peningkatan pengetahuan, secara statistik menunjukan terdapat pengaruh intervensi Pendidikan terkait gizi dan kesehatan reproduksi pada remaja terhadap pengetahuan.

Diharapkan peningkatan pengetahuan terkait gizi dan kesehatan reproduksi pada pertemuan ini dapat mengubah sikap dan perilaku remaja untuk sadar gizi, memantau berat badan dan kesehatan secara rutin. 


\section{DAFTAR PUSTAKA}

Departement of Health and Human Service. (2000). Healthy People 2010 Volume II. Washington: Goverment Printing Office .

Jukes, M. C., \& Bundy, L. J. (2008). School Health, Nutrition and Education for All Leveling the Playing Field. USA: CABI International.

Machfoedz, I., \& Suryani, E. (2009). Pendidikan Kesehatan Bagian Dari Promosi Kesehatan. Yogyakarta: Fitramaya.
Marcell, A. V., Wibbelsman, c., \& Seigel, W. M. (2011). Male Adolescent Sexual and Reproductive Health Care. PEDIATRICS, 1658-1676.

Soejoeti, S. Z. (2001). Perilaku Seks di Kalangan Remaja dan Permasalahannya. Media Litbang Kesehatan Volume XI No 1 , 30-35.

Wijaya, I. M., Agustini, N. N., \& MS, G. D. (2014). Pengetahuan, Sikap dan Aktivitas Remaja SMA dalam Kesehatan Reproduksi di Kecamatan Buleleng. Kesehatan Masyarakat, 33-42. 